\title{
Learning Type, Learning Motivation, and Grade Performance Achievement of Students in Vocational Higher Education
}

\author{
Anas Arfandi \\ Engineering Faculty \\ Universitas Negeri Makassar \\ Makassar, Indonesia \\ anas.arfandi@unm.ac.id
}

\author{
Akshari Tahir Lopa \\ Engineering Faculty \\ Universitas Negeri Makassar \\ Makassar, Indonesia
}

\begin{abstract}
Learners have different ways of understanding a subject matter. Teacher adjustment to the characteristics of learners greatly helps learners in achieving mastery learning. Learners who are highly motivated in learning have a great opportunity in obtaining high learning achievement. The purpose of this study was: 1) to describe the learning type of students. 2) to explain the learning motivation of students. 3) to describe the students' GPA based on their learning type. 4) to explain the influence of learning type of learners to the students' GPA. 5) to describe the influence of learning motivation on the students' GPA. 6) to explain the effect simultaneously between the types of learning and learning motivation on the students' cumulative achievement index. This research is a survey research. The subject of this research was the students of the department of civil and planning engineering education Universitas Negeri Makassar. Data were collected using a questionnaire and documentation. The data was analyzed descriptively and inferential analysis. The results showed: first, Students in the department of civil and planning engineering education Universitas Negeri Makassar had dominant in kinesthetic learning types, and $81 \%$ of them were women. Second, $90 \%$ of learners have high learning motivation, although there are still learners have low learning motivation. Third, Learners with Visual learning types have the highest GPA compared to other types of learning such as Auditorial and Kinaesthetic. Forth, The type of visual learning has a positive and significant influence on the GPA, while the auditory and kinesthetic learning types do not affect. Fifth, The motivation of learning has a positive and significant influence on the GPA. Sixth, The type of learning and motivation to learn simultaneously provides a positive and significant impact on the GPA.
\end{abstract}

Keywords-Skills learning type, learning motivation, vocational higher education

\section{INTRODUCTION}

Teachers are the key to learning activities. The ability to adapt the learner's cognitive development is an important thing. Teacher adjustment to the characteristics of learners will significantly help learners achieve learning mastery [1]. Even so, all teachers have the same goal of transforming science, shaping students' attitudes, and making learners skilled in their work.

Application of the curriculum accompanied by the teaching indirectly fosters the spirit and motivation of learners to learn a subject. Learning motivation that arises in the learners is caused by the ideals or the drive to obtain the expected results. Learners who are motivated highly in learning have a great opportunity in obtaining high learning achievement. While the motivation higher, the intensity of effort to achieve the desired learning achievement will also be higher [2]. It happens when teacher involve learners to interfere with the teaching and learning process [3].

Learners have different ways of understanding a subject matter. Some learners prefer when teachers teach by writing everything on the board, while others prefer it when teachers teach by lecture method, and learners listen to be able to understand it [4]. When teaching by lecture method, teachers are expected to explain various theories with a diverse of illustrations, at the same time learners were listening while describing the content in their perspective [5].

In the learning process, learners have different types of learning differences. Grouping the learning type according to DePorter [6] that is by seeing (visual), by listening (auditorial), and learning by doing (kinesthetic). An appropriate type of learning is the key to one's success in learning. The manner in which these learners learn varies is called the learning type [7]. Type of learning is one aspect that needs attention which is the easiest way that individuals have in absorbing, organizing and processing information received.

A person's ability to understand and absorb the lessons is different. The difference between the types of learning shows the quickest and best way for any individual to absorb information from outside himself [8]. Therefore, as a teacher can understand how different types of learning are to his students, and try to alert his students to the differences, it may be easier for teachers to convey information more effectively and efficiently [9].

Based on the background several issues will be examined, namely: 1) how to describe the different types of student learning in the department of civil and planning engineering education Universitas Negeri Makassar?. 2) how is the learning motivation of students in civil and planning engineering education Universitas Negeri Makassar?. 3) how does the Grade Performance Achievement (GPA) of learners based on their learning type?. 4) how is the influence of learners' type of GPA?. 5) how is the influence of learning motivation on student GPA? and 6) how is the simultaneous 
influence between study type and learning motivation toward student GPA?

\section{METHOD}

\section{A. Research Design}

This study is survey research, which analyzed the learning types of learners and students learning motivation as an independent variable and cumulative achievement index as a dependent variable.

\section{B. Sample Size and Sampling Technique}

The population of this study was all active students in the Department of civil and planning engineering education Universitas Negeri Makassar academic year 2017/2018. It used random sampling by determining the number of samples using proportionated sampling. The number of samples obtained was as many as 125 respondents consisting of 58 men and 67 women.

\section{Instrument}

The data was collected by a questionnaire adopted from a learning type instrument of DePorter [10] with 59 questions divided into 20 questions to measure the type of Visual learning, 19 questions for Auditorial learning type, and 20 questions for kinesthetic learning type. Motivational learning instruments adopted from Pintrich [11]-[13] consisting of 44 question items. The instrument of GPA obtained from the documentation of Students' Academic Achievement.

\section{Data Analysis}

Data analysis techniques used descriptive and inferential. The inferential analysis was conducted to measure the influence of variables, after meeting the requirements analysis test. Furthermore, Pearson product moment coefficient of correlation ( $r$ ) was computed to determine the correlation of all learning types in three factors namely Visual $\left(\mathrm{X}_{1}\right)$, Auditorial $\left(\mathrm{X}_{2}\right)$, Kinesthtic $\left(\mathrm{X}_{3}\right)$, and Learning Motivation $\left(\mathrm{X}_{4}\right)$ to Learning Achievement measured from Grade Performance Achievement (GPA). All statistical tests were set at .05 level of significance.

\section{RESULT AND DISCUSSION}

\section{A. Student's Learning Type}

The results of the study on 125 respondents showed the data as outlined in Table I

TABLE I. DESCRIPTION OF DISTRIBUTION OF STUDENT LEARNING TYPE

\begin{tabular}{|l|c|c|c|}
\hline \multirow{2}{*}{ Learning type } & \multirow{2}{*}{ Percentage } & \multicolumn{2}{c|}{ Percentage of Sex } \\
\cline { 3 - 4 } & & Male & Female \\
\hline Visual & 26.09 & 39.13 & 60.87 \\
\hline Auditory & 27.54 & 64.41 & 35.59 \\
\hline Kinesthetic & 46.38 & 19.05 & 80.95 \\
\hline
\end{tabular}

Table I shows that female learners are more dominant in kinesthetic and visual learning types, while male learners are more dominant in auditory learning types. It is similar to Ames [4] study which stated that there are different learning types of learners from sex perspective. It was showed from the attitude of learners in operating the computer. Knight,
Elfenbein, \& Martin [5] have previously explained that women are more different than men regarding concrete experience. Psychologically, female learners are better prepared when compared to the readiness of male learners. Orhun's [14] study results that there is a difference between the preferred type of learning by female and male learners, mathematical achievement, and their attitudes toward mathematics. However, their achievements and attitudes toward mathematics do not depend on gender. The female learners are most likely of Convergent learning types, while male learners are most interested in the type of Assimilator learning. However, none of the learners chose the Accommodator learning in both groups.

\section{B. Students Learning Motivation}

Students learning motivation measure by motivational and self-regulated learning (MSLR) which adopt from Pintrich as shown in Table II.

TABLE II. STUDENTS LEARNING MOTIVATION

\begin{tabular}{|l|c|c|c|}
\hline \multirow{2}{*}{ Category } & \multicolumn{2}{|c|}{ Percentage } & \multirow{2}{*}{ Amount } \\
\cline { 2 - 3 } & Male & Female & \\
\hline High & 40.58 & 49.28 & 89.86 \\
\hline Medium & 4.35 & 2.90 & 7.25 \\
\hline Low & 1.45 & 1.45 & 2.90 \\
\hline
\end{tabular}

Table II shows that the learning motivation of students dominant in the High category. However, there are $7.25 \%$ in the Medium category and $2.90 \%$ which is still Low. On the other hand, the respondents who have high learning motivation, most of them are female students.

Vansteenkiste, Simons, Lens, Sheldon, \& Deci [2] stated that the optimally use of intrinsic motivation by learners who are framed by teachers in learning activities and a good learning climate would have a significant impact on their dedication and liveliness of learners. It implies in the design of optimal learning environment. Furthermore, The relationship between motivation and learning type as described by Boekaerts [7], [15] that the learning type in a student will help him in self-regulated to do something so that he/she can understand easily of the learning.

\section{Grade Performance Achievement (GPA)}

GPA collected from learning achievement document which stored at head department of civil and planning engineering education Universitas Negeri Makassar. The result shows at Figure 1.

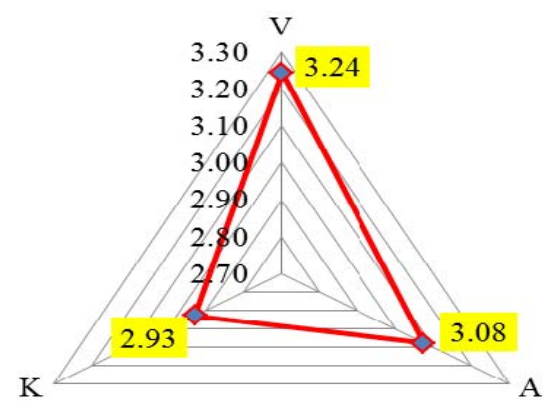

Fig. 1. The average value of respondents by type of learning

From Figure 1 shows that the average of respondents' GPA with visual learning type is higher than others learning 
type, while the lowest learning outcomes are in respondents who have Kinesthetic learning. Nevertheless, their GPA is still in the category of Very satisfactory. Dunn [16] suggest that educators consider all learners' learning power to maximize instructional results.

Students learning motivation measure by motivational and self-regulated learning (MSLR) which adopt from Pintrich as shown in Table 2.

\section{The Influence of Learning Type and Learning Motivation to GPA}

Before the data analyzed by regression equation, it must meet the requirements of normality, linearity, and multicollinearity test. Test results as seen in Table III.

TABLE III. DATA ANALYSIS REQUIREMENT

\begin{tabular}{|c|c|c|c|c|}
\hline \multirow{2}{*}{ Variable } & \multicolumn{2}{|c|}{ probability $(\rho)$} & \multicolumn{2}{c|}{ Colleniarity } \\
\cline { 2 - 5 } & Normality & Linearity & $\begin{array}{c}\text { Standard } \\
\text { error }\end{array}$ & VIF \\
\hline Visual & .383 & .447 & .013 & 1.172 \\
\hline Auditory & .107 & .855 & .012 & 1.214 \\
\hline Kinesthetic & .156 & .425 & .009 & 1.259 \\
\hline $\begin{array}{c}\text { Learning } \\
\text { Motivation }\end{array}$ & .614 & .221 & .001 & 1.182 \\
\hline
\end{tabular}

Based on the above table that the probability value $(\rho)$ of all variables indicates a value higher than the significance value $\alpha(0.05)$, it can be concluded that the data distributed Normally. In linearity test, the variable data of Visual learning type, Auditory learning type, Kinesthetic learning type, and learning motivation get probability value $(\rho)$ greater than significance value $\alpha(0.05)$. Multicollinearity test showed that standard error value is less than 1 and VIF value less than 10. Thus, it can be concluded that the variables of Visual, Auditory, Kinesthetic learning type, and learning motivation there is no multicollinearity.

Hypothesis testing was using simple regression. A simple linear regression analysis was performed to determine the effect of one independent variable on the dependent variable. The criterion used based on probability value $(\rho)$. Also, the decision making can also by comparing the value of Fvalue with Ftable. The result of simple linear regression analysis of the independent variable to the dependent variable presented in Table IV.

TABLE IV. HiPOTHETICAL RESUlT

\begin{tabular}{|c|c|c|c|c|c|c|}
\hline No. & Variable & $\mathbf{R}$ & Rsquare & F value & $\rho$ & F table \\
\hline 1 & $\mathrm{X} 1 \rightarrow \mathrm{Y}$ & 0,253 & 6,40 & 4,586 & 0,036 & 3,96 \\
\hline 2 & $\mathrm{X} 2 \rightarrow \mathrm{Y}$ & 0,044 & 0,20 & 0,128 & 0,722 & 3,96 \\
\hline 3 & $\mathrm{X} 3 \rightarrow \mathrm{Y}$ & 0,065 & 0,40 & 0,288 & 0,593 & 3,96 \\
\hline 4 & $\mathrm{X} 4 \rightarrow \mathrm{Y}$ & 0,410 & 16,80 & 13,502 & 0,000 & 3,96 \\
\hline
\end{tabular}

Based on the Table IV, it is shown that the correlation coefficient of visual learning type $\left(\mathrm{X}_{1}\right)$ is 0.253 in positive sign, probability $(\rho)$ value $0.036<0.05$, while $F_{\text {value }} 2.679>$ $F_{\text {table }}$ 1.996. Based on this result it can be concluded that the variables of visual learning type give positive influence to GPA. The coefficient of determination of visual learning type variables to GPA is $6.40 \%$ which means that $93.60 \%$ of GPA is determined by other factors outside of the type factor of visual learning.

The correlation coefficient of auditorial learning type $\left(\mathrm{X}_{2}\right)$ is 0,044 with positive sign, probability $(\rho)$ value $0,722>$ 0,05 , while $F_{\text {value }} 0,128<F_{\text {table }} 3,96$. Based on this result it can be concluded that variable of the type of auditorial study does not give positive influence to a variable of student GPA. The coefficient of determination of variables of the learning to the GPA is minimal at $0.20 \%$. It means that $99.80 \%$ of GPA of learners is determined by other factors outside of the type of learning factor is auditorial.

The correlation coefficient of kinesthetic learning variable type $\left(\mathrm{X}_{3}\right)$ is 0,065 marked positive, probability $(\rho)$ value $0,593>0,05$, while $F_{\text {value }} 0,128<F_{\text {table }} 3,96$. Based on this result, it can be concluded that kinesthetic learning type variable does not give positive influence to student GPA. The coefficient of determination of the kinesthetic learning type variable to the GPA is $0.40 \%$ which means that $99.60 \%$ GPA of learners is determined by other factors outside the kinesthetic learning type factor.

The correlation coefficient of learning motivation variable $\left(\mathrm{X}_{4}\right)$ is 0,410 marked positive, probability $(\rho)$ value $0,000<0,05$, while $F_{\text {value }} 13,502>F_{\text {table }} 3,96$ so it can be concluded that learning motivation variable give positively influence to variable of Student GPA. The coefficient of determination of learning motivation variable to GPA is $16.80 \%$ which means that other factors outside of learning motivation determine $83.20 \%$ of GPA.

These results indicate that the type of visual learning and learning motivation have a positive and significant influence on the Grade Performance Achievement (GPA), while the auditory and kinesthetic learning types do not affect. The results of this study are quite different from Gilakjani [8] study which explains that the improvement of learning quality depends on the type of learners' learning, the use of effective and fun learning type can increase the motivation and learning outcomes of the students although the material taught is quite complicated. Allcock \& Hulme [1] stated that the type of teacher teaching which adapts to the characteristics of learners shows the persistence of teachers in helping learners achieve mastery learning. It can be expected that student achievement is not affected by the type of student learning but caused by the type of teacher teaching who are not optimize in helping the type of student learning.

The results of this study reinforce the statement of Duncan \& McKeachie [9], [17] which explains that students who are motivated highly in learning have a great opportunity in obtaining high learning achievement. The higher motivation will intent the effort to achieve the desired learning achievement. It also related to the research results of Cassidy \& Eachus [18] who concluded that the GPA is correlated positively with learning strategy approach. Type learning is correlated significantly with academic performance associated with academic success and academic locus of control. Nevertheless, GPA does not correlate to apathy approach and in-depth learning approach.

In this regard, Dunn, Beaudry, \& Klavas [19], [20] have explained that there is no better or worse learning type because each type has the same range of intelligence. Learners cannot be stigmatized because they have any learning type. Most learners can master the same 
competence, but their respective types determine the way of satisfaction.

\section{CONCLUSION}

Students in the department of civil and planning engineering education Universitas Negeri Makassar dominantly have kinesthetic learning types, and $81 \%$ of them are women. $90 \%$ of students have High learning motivation, although there are still learners with Low learning motivation. Learners with Visual learning types have the highest GPA compared to other types of learning, but all of it still in the category of Very Satisfactory. The type of visual learning has a positive and significant influence on the Grade Performance Achievement (GPA), while the auditory and kinesthetic learning types do not affect. The learning motivation has a positive and significant influence on the Grade Performance Achievement (GPA). The type of learning and motivation to learn simultaneously provided a positive and significant impact on the Grade Performance Achievement (GPA).

\section{ACKNOWLEDGMENT}

The author would like to thank the Rector of Universitas Negeri Makassar who funded this research through PNBP fund.

\section{REFERENCES}

[1] [1] S. J. Allcock and J. A. Hulme, "Learning Styles in the Classroom: Educational Benefit or Planning Exercise?.," Psychol. Teach. Rev., vol. 16, no. 2, pp. 67-79, 2010.

[2] [2] M. Vansteenkiste, J. Simons, W. Lens, K. M. Sheldon, and E. L. Deci, "Motivating learning, performance, and persistence: the synergistic effects of intrinsic goal contents and autonomy-supportive contexts.," J. Pers. Soc. Psychol., vol. 87, no. 2, p. 246, 2004.

[3] [3] A. Honigsfeld and R. Dunn, "High school male and female learning-style similarities and differences in diverse nations," J. Educ. Res., vol. 96, no. 4, pp. 195-206, 2003.

[4] [4] P. C. Ames, "Gender and learning style interactions in students' computer attitudes," J. Educ. Comput. Res., vol. 28, no. 3, pp. 231244, 2003.

[5] [5] K. H. Knight, M. H. Elfenbein, and M. B. Martin, "Relationship of connected and separate knowing to the learning styles of Kolb, formal reasoning, and intelligence," Sex Roles, vol. 37, no. 5, pp. 401-414, 1997.

[6] [6] B. Deporter and M. Hernacki, "Quantum pathways: Discovering your personal learning style," 2000.

[7] [7] M. Boekaerts, "Self-regulated learning: Where we are today," Int. J. Educ. Res., vol. 31, no. 6, pp. 445-457, 1999.

[8] [8] A. P. Gilakjani, "Visual, auditory, kinaesthetic learning styles and their impacts on English language teaching," J. Stud. Educ., vol. 2, no. 1, pp. 104-113, 2011

[9] [9] T. G. Duncan and W. J. McKeachie, "The making of the motivated strategies for learning questionnaire," Educ. Psychol., vol. 40, no. 2, pp. 117-128, 2005.

[10] [10] B. DePorter, M. Reardon, and S. Singer-Nourie, Quantum teaching: Orchestrating student success. Allyn \& Bacon, 1999.

[11] [11] P. R. Pintrich, "Motivational beliefs as resources for and constraints on conceptual change," New Perspect. Concept. Chang., vol. 33, p. 50, 1999.

[12] [12] Y. Li, J. Medwell, D. Wray, L. Wang, and L. Xiaojing, "Learning Styles: A Review of Validity and Usefulness," J. Educ. Train. Stud., vol. 4, no. 10, pp. 90-94, 2016.

[13] [13] T. F. Hawk and A. J. Shah, "Using learning style instruments to enhance student learning," Decis. Sci. J. Innov. Educ., vol. 5, no. 1, pp. 1-19, 2007.

[14] [14] N. Orhun, "An investigation into the mathematics achievement and attitude towards mathematics with respect to learning style according to gender," Int. J. Math. Educ. Sci. Technol., vol. 38, no. 3, pp. 321-333, 2007.

[15] [15] J. O. Papilaya and N. Huliselan, "Identifikasi gaya Belajar Mahasiswa," J. Psikol., vol. 15, no. 1, pp. 56-63, 2016.

[16] [16] R. Dunn, A. Honigsfeld, L. S. Doolan, L. Bostrom, K. Russo, M. S. Schiering, B. Suh, and H. Tenedero, "Impact of learning-style instructional strategies on students' achievement and attitudes: Perceptions of educators in diverse institutions," Clear. House A J. Educ. Strateg. issues ideas, vol. 82, no. 3, pp. 135-140, 2009.

[17] [17] R. M. Felder and R. Brent, "Understanding student differences," J. Eng. Educ., vol. 94, no. 1, pp. 57-72, 2005.

[18] [18] S. Cassidy and P. Eachus, "Learning style, academic belief systems, self-report student proficiency and academic achievement in higher education," Educ. Psychol., vol. 20, no. 3, pp. 307-322, 2000.

[19] [19] R. Dunn, J. S. Beaudry, and A. Klavas, "Survey of research on learning styles," Calif. J. Sci. Educ., vol. 2, no. 2, pp. 75-98, 2002.

[20] [20] M. H. Jikamshi, M. C. Abdullah, S. Roslan, and H. Ismail, "Dimensions of Epistemological Beliefs, Learning Goal Orientation, as Predictors of Deep Knowledge Acquisition Approach among PreService Teachers in Nigeria," Mediterr. J. Soc. Sci., vol. 7, no. 4, p. $165,2016$. 